\title{
Optimizing the tensile strength of concrete containing coal waste considering the cost
}

\author{
Behnoosh Khataei ${ }^{1} \cdot$ Meisam Nasrollahi ${ }^{2}$
}

Received: 20 September 2019 / Accepted: 10 December 2019 / Published online: 17 December 2019

(c) Springer Nature Switzerland AG 2019

\begin{abstract}
Nowadays, removal of the waste from industrial activities is one of the serious problems in the world. Contrarily, needing the development of industrial construction and reduce its costs, with considering the construction quality, are the main priorities of progress. Therefore, in this paper, for the first time, all these issues are considered related to using the waste of coal extraction; also, the application of coal wash rejects in the concrete manufacture and its impact on tensile strength of concrete have been investigated. To this goal, coal waste was prepared from the Central Alborz Coal Preparation Plant in northern Iran. Designing the experiments by the response surface methodology (RSM), the influence of parameters like water/cement $(0.4-0.6)$, cement content $\left(305-445 \mathrm{~kg} / \mathrm{m}^{3}\right)$, aggregate volume $(0.4-0.6 \%)$ and coal waste $(0.5-9.75 \%)$ on the tensile strength to cost of concrete construction were evaluated. Presenting the model, optimizing and investigating the individual, reciprocal and simultaneous effects of independent variables on the tensile strength to cost of concrete by RSM were conducted for the first time. Based on the results of tensile strength tests and estimating the cost of concrete construction, the highest ratio of tensile strength to cost was obtained by using the cement content of $340 \mathrm{~kg} / \mathrm{m}^{3}$, water/cement of 0.45 , gravel volume of $0.55 \%$ and coal waste of $7.5 \%$. In this case, the response value was $1.29 \mathrm{E}-6 \mathrm{MPa} / \mathrm{USD}$. These results indicate the high potential of these wastes in the production of concrete in terms of tensile strength and also economic aspect.
\end{abstract}

Keywords Portland cement $\cdot$ Coal washery rejects $\cdot$ Concrete tensile strength $\cdot$ Cost $\cdot$ Optimization $\cdot$ Response surface methodology

\section{Introduction}

Nowadays, most industrial factories produce much waste along with the production of one of the main products or more, which is largely disposed directly in the environment. The accumulation of these wastes over time has caused many environmental problems; so that, today waste management issues are seriously discussed in the context of environmental protection. On the other hand, rapid development of construction industries and consuming the natural resources have led to reduction of natural resources and environmental degradation by various ways. Therefore, many efforts have been made focusing on by-products and industrial wastes in order to protect the natural resources $[3,4,12,17,26,29,32,43,44,57]$. For example, reducing the use of construction materials by applying the industrial wastes in concrete is a positive step towards sustainable development [15].

In this regard, several researchers have used coal mining wastes [40-42], fly ash [21,36], bottom ash [1, 16, 20, $38,47,48]$, Pond ash [55], coal ash [18, 37]; slag products [58], coal mine overburden [19], copper slag [2, 7], blast furnace slag $[45,56]$, steel fibers [6], waste ceramic tile [52]

Behnoosh Khataei, b.khataei@modares.ac.ir|' Department of Civil and Environmental Engineering, Tarbiat Modares University, Tehran, Iran. ${ }^{2}$ Faculty of Civil Engineering, Babol Noshirvani University of Technology, Babol, Iran. 
and recycled plastic $[39,46]$ as an alternative of concrete components.

In summary, during the process of coal washing, the coal washed by the water flow gets into the pond and waste sinks. The waste is removed continuously from the washer, then stored in the tank. This waste is named coal washery rejects (CWR) [13]. Reuse of waste, meanwhile preventing environmental pollution, reduces the volume of disposed coal waste and leads to the clean production of coal. Because, their reuse in the construction industry is one of the essential steps in the planning of solid waste management towards the sustainable development. It is also possible to replace the natural resources in various industries by coal waste. Therefore, the consumption of natural resources is reduced. Different methods like as biological, chemical or physical methods had been used in environmental engineering for solving environmental pollutants $[11,25,27,28,30,35,51]$. In this regard, several studies have been done on the use of coal waste in the concrete industry, in which the above waste replaces aggregates or cement in concrete [9].

Due to global growth of infrastructure in the world, demand of concrete has increased considerably. Therefore, the use of alternative sources instead of cement and aggregates is a challenging necessity. In this way, recycled materials and waste can be used as alternative sources in concrete, which assist in reduction of waste and extreme use of energy and natural resources like aggregate mining. In addition, gases emission gets limited [50].

Heidari et al. [10] investigated the possible solutions to use of solid waste from coal washing plant (Zarand in Kerman province) in the cement industry. Because the accumulation of these wastes in the area around the coal mill leads to the production and diffusion of very soft particles in the surrounding area, the penetration of toxic metals such as arsenic and mercury into soils and underground waters and the release of radioactive substances like uranium; Meanwhile, the increase in the daily disposal volume causes occupancy of the surrounding area. The researchers stated that using the solid waste of coal washing plant in the cement industry, while removing its negative effects on the environment, has led to savings the energy (fossil fuels and cement raw materials). The experiments resulted that the compressive strength of type II cement made from wastes was higher than that of the control sample, with 3 -day strength of about $4 \%$ and 28 -day strength of $3.2 \%$ increase.

In the study of Naqipour et al. [23], coal waste was evaluated as a substitute of cement and fine-grained materials in the manufacture of concrete with a target compressive strength of 20 and $31 \mathrm{MPa}$. Based on the resulted compressive strengths, the best percentage of sand and cement replacement with the coal waste powder, was achieved respectively about $10 \%$ and $5 \%$ (for 28 -day samples). Kuamr et al. [17] conducted a study on the replacement of coarse aggregates in concrete by coal washery rejects. While reviewing different replacement levels (0 to $50 \%$ ), they reported $30 \%$ of the aggregate replacement by coal washery rejects as the optimum level in construction industry.

Sudharshan and Kumar [49] studied the changes in compressive strength, weight, and ultrasonic pulse velocity before and after the acid attack of three types of concrete. $M$ 25 grade of concrete cubes, by the concrete types including conventional concrete (CC), concrete with $30 \%$ replacement of coarse aggregates by coal washery rejects (CWR_30) and concrete with $30 \%$ replacement of coarse aggregates by coal washery rejects and also $30 \%$ replacement of cement by fly ash (FCWR_30), were prepared and compared. They found that the FCWR_30 had a similar function to CC and more efficiency than CWR_30 in acidic environments. In the study of Sumalatha et al. [50], the durability properties of concrete containing fly ash and different levels of coal washery rejects was investigated. Properties such water absorption, RCPT, and drying shrinkage were compared to conventional concrete (M 25 grade). The results showed that applying the fly ash as a substitute of fine aggregates or cement caused a significant increase in concrete compressive strength, and also using the $30 \%$ of coal washery rejects improved the concrete structure.

Considering that the economic aspect of applying the coal extraction waste in concrete as well as the tensile strength of concrete has not been addressed in previous researches, replacement of cement by waste of coal washing plant in Central Alborz mine in concrete, checking the tensile strength and economic value of the resulted concrete have been investigated in this research. Also, the simultaneous effect of variables, their interaction, and the optimization and modeling of results in the production of concrete from the waste is not been addressed in previous studies. In this regard, in order to achieve the highest efficiency with the least number of experiments (thus reducing the costs and consumed substances), process optimization was done by statistical methods including the response surface methodology. It should be noted that using these wastes as a combination of cement replacement and reinforcement is another new aspect of this research. In this study, the 28-day tensile strength of concrete samples was investigated.

\section{Materials and methods}

\subsection{Materials}

Coal waste (waste): coal waste used in this study is prepared from Central Alborz Coal Factory, located in the 
Table 1 Chemical properties of coal waste

\begin{tabular}{llllllllllll}
\hline Items & $\mathrm{SiO}_{2}$ & $\mathrm{Al}_{2} \mathrm{O}_{3}$ & $\mathrm{Fe}_{2} \mathrm{O}_{3}$ & $\mathrm{MgO}$ & $\mathrm{CaO}$ & $\mathrm{P}_{2} \mathrm{O}_{5}-\mathrm{P}_{2} \mathrm{O}_{3}$ & $\mathrm{Na}_{2} \mathrm{O}$ & $\mathrm{K}_{2} \mathrm{O}$ & $\mathrm{MnO}$ & $\mathrm{TiO}_{2}$ & L.O.I \\
\hline Coal waste & 37.8 & 13.14 & 2.85 & 0.73 & 0.76 & 0.27 & 0.28 & 2.02 & 0.02 & 1.17 & 40.96 \\
\hline
\end{tabular}

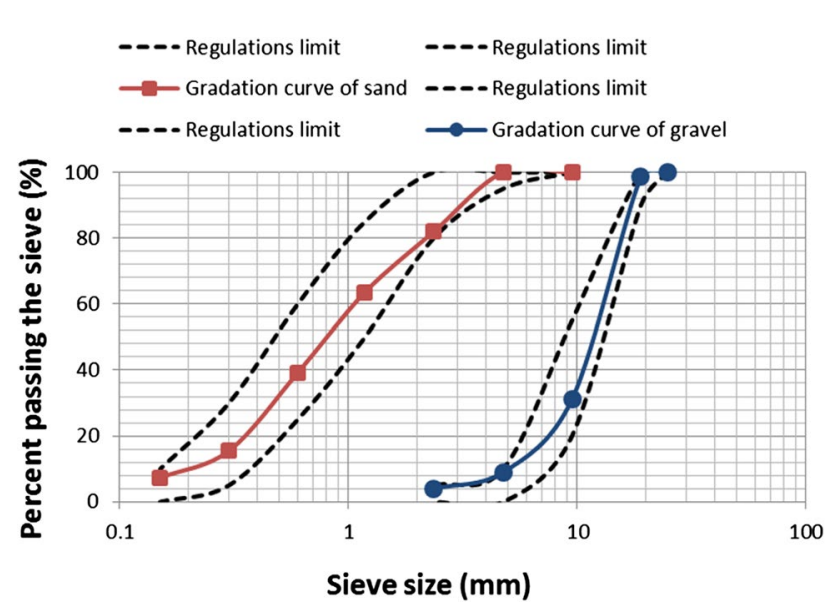

Fig. 1 Sieving curve of used natural aggregates

Anjirtangeh Zirab region of Northern Iran. These materials are produced in the process of coal washing to convert to coal concentrate for use as fuel in the industry. Since the factory started in 1989 to today, wastes have been accumulated in the area of 2 ha and elevations of over 10 meters, estimated to be more than 2 million tons [22]. In this research, used coal wastes have dry density of $1.24 \mathrm{~g} / \mathrm{cm}^{3}$ and compressive strength of $25 \mathrm{MPa}$. After passing through the sieve no. $200(0.075 \mathrm{~mm})$, these materials replaced the cement by various amounts. Replacement percent of coal wastes is different in concrete mixing plans. Chemical analysis of used coal waste is presented in Table 1.

Aggregates: Used gravel has the dry density of $1.57 \mathrm{~g} /$ $\mathrm{cm}^{3}$ and maximum size of $12.5 \mathrm{~mm}$. Sieving curve, shown in the Fig. 1, was in the standard range (ASTM C33). More, properties of aggregates are provided in Table 2.

Cement: In this study, type II Portland cement by softness of $3570 \mathrm{~cm}^{2} / \mathrm{g}$ (prepared from Gorgan Cement Factory) was used. Table 3 presents the physical and chemical properties of cement.

Water: Impurities in the water may affect the cement hardening and create disturbances in it. Also, use of improper water can have a reverse effect on the concrete strength, causing stains on the concrete surface and even corrosion of the reinforcement. Therefore, in most mixes, suitable water for concrete is that suitable for drinking [24]. So, drinking water was used to make concrete samples in this research.
Table 2 Properties of aggregates

\begin{tabular}{lll}
\hline Aggregate & Gravel & Sand \\
\hline Specific gravity $\left(\mathrm{g} / \mathrm{cm}^{3}\right)$ & 2.52 & 2.76 \\
Unit weight $\left(\mathrm{g} / \mathrm{cm}^{3}\right)$ & 1.59 & 1.73 \\
Moisture content (\%) & 0.14 & 0.3 \\
Moisture of saturated surface dry (\%) & 0.4 & 0.5 \\
Fines modulus (FM) & - & 2.89 \\
Sand equivalent value (SE) (\%) & - & 84 \\
\hline
\end{tabular}

Table 3 Physical and chemical properties of cement

\begin{tabular}{ll}
\hline Component & Test result \\
\hline $\mathrm{SiO}_{2}$ & 20.8 \\
$\mathrm{Al}_{2} \mathrm{O}_{3}$ & 5.24 \\
$\mathrm{Fe}_{2} \mathrm{O}_{3}$ & 3.6 \\
$\mathrm{CaO}$ & 64 \\
$\mathrm{MgO}$ & 1.63 \\
$\mathrm{SO}_{3}$ & 2.48 \\
$\mathrm{L.O.I}$ & 1.92 \\
$\mathrm{Blaine}\left(\mathrm{cm}^{2} / \mathrm{g}\right)$ & 3322 \\
Expansion (autoclave) \% & 0.073 \\
Compressive strength $\left(\mathrm{kg} / \mathrm{cm}^{2}\right)$ & \\
3 days & 296 \\
7 days & 400 \\
28 days & 530 \\
\hline
\end{tabular}

\subsection{Methodology of experiments planning to evaluate the concrete mixing plan}

Modeling of environmental phenomena have been studied many times. Response surface methodology is one of the most used methods in environmental studies [5, $8,14,31,33,34,53,54]$. Statistical methods have many advantages compared with the traditional ones due to the rapid calculations and the identification of relationships between effective factors. Today, a variety of planning methods are used to reduce the costs and increase the accuracy of tests. One of the newest experimental design methods is Response Surface Methodology (RSM). The central composition design (CCD) method as a subset of RSM is the most well-known design method among second-order methods, first introduced by Box. It needs attention that in this study, CCD was used by Design Expert 10.0.1 software to design the experiments and analysis the results. 
For this purpose, 4 parameters including water to cement ratio, cement content, gravel volume and wastes percentage (each in 5 levels) as the variables and tensile strength to cost ratio as the response were considered. In Table 4, these factors are presented along with the levels set for each one (according to previous studies). Then, 30 experiments were designed by software (with 6 replications at the central point), after which the optimum conditions were determined.

In order to determine the cost of concrete construction with the above mixing designs of the mixes, the price of $1 \mathrm{~kg}$ of cement, gravel and sand, and $1 \mathrm{~m}^{3}$ of water were considered with asking from the materials companies. It should be noted that coal waste was not included in the cost calculation. In Table 5, the experiments designed in RSM are presented. After the construction of concrete cylinders according to the mixing plans and calculation of the ratio of tensile strength to cost, the analysis of the results was done by the software. Afterward, to validate the model, the confirmation test (optimum test obtained from the software) was repeated twice.

\subsection{Experimental method}

According to ISRM 77, concrete cylinders by a diameter of at least $54 \mathrm{~mm}$ and a height equal to the diameter were constructed based on the mixing design determined by the RSM (presented in Table 5). Concrete samples were initially treated for 7 days in a humid environment, then 21 days at $21^{\circ} \mathrm{C}$ and $21 \%$ relative humidity. After 28 days, they were tested in Brazil method according to ASTM C293-79 standard, to determine the tensile strength indirectly.

\section{Results and discussion}

As mentioned before, 4 parameters of the water to cement ratio, cement content, gravel volume and wastes percentage as variables and the ratio of tensile strength to cost as the response were considered in the software. The factors and levels, presented in Table 4, were determined according to the other studies. Then, based on 30 mixing designs of this method, concrete samples were made in the cylindrical molds (introduced in the previous section) and tested for tensile strength. The response values are shown in Table 5. In the following, these results are presented in graphs and more discussions are presented.

\subsection{The individual effects of variables}

In this section, the individual effect of variables (water to cement ratio, cement content, gravel volume and waste percentage on the response the tensile strength to cost ratio) is considered (Fig. 2). Figure 2a displays the effect of water to cement ratio on the mentioned response at constant values for other parameters. It is observed that increasing in the water to cement ratio caused to reducing the response. Such a way that, in water to cement ratio of 0.45 to 0.48 , the response is nearly invariant; afterward, in water to cement ratio of 0.48 to 0.55 , a significant descending slope is observed in the response. In Fig. $2 b$ the effect of cement content on the ratio of tensile strength to cost, can be seen. Based on the results, at constant values for other parameters (waste percentage of $5.25 \%$, gravel volume of $0.5 \%$, and water to cement ratio of 0.5 ), when cement content increases from 340 to 376 and then to $412 \mathrm{~kg} / \mathrm{m}^{3}$, the tensile strength to cost ratio respectively increases and then decreases with a slight slope. In continue, the effect of gravel volume on the investigated response (considering constant values for other parameters) is shown in Fig. 2c. Regarding the figure, the changes of tensile strength to cost ratio due to increasing the gravel volume is similar to the changes affected by the cement content (Fig. 2b), but with more noticeable slope. This result indicates the greater impact of gravel volume than the cement content. Figure $2 \mathrm{~d}$ presents the effect of waste percentage on the ratio of tensile strength to cost (with other parameters as constants: gravel volume of $0.5 \%$, cement content of $376 \mathrm{~kg} / \mathrm{m}^{3}$, and water to cement ratio of 0.5 ). As the percentage of waste increases from 3 to $7.5 \%$, the response has a gradual decreasing trend.
Table 4 Parameters and levels to optimize the concrete mixing plan

\begin{tabular}{lllllll}
\hline Parameter & Unit & \multicolumn{2}{l}{ Levels } & & \\
\cline { 2 - 6 } & & -2 & -1 & 0 & 1 & 2 \\
\hline Water to cement ratio & - & 0.4 & 0.45 & 0.49 & 0.55 & 0.6 \\
Cement content & $\mathrm{kg} / \mathrm{m}^{3}$ & 305 & 340 & 375 & 412 & 445 \\
Gravel volume & $\%$ & 0.4 & 0.45 & 0.49 & 0.55 & 0.6 \\
Wastes percentage & $\%$ & 0.75 & 3 & 5.25 & 7.5 & 9.75 \\
\hline
\end{tabular}


Table 5 Experimental design to optimize the ratio of tensile strength to cost in concrete containing the coal waste

\begin{tabular}{|c|c|c|c|c|c|}
\hline \multirow[t]{2}{*}{ No. } & \multicolumn{4}{|c|}{ Factors and levels } & \multirow{2}{*}{$\begin{array}{l}\text { Response } \\
\text { Tensile strength to cost }\end{array}$} \\
\hline & $\begin{array}{l}\text { Water to } \\
\text { cement ratio }\end{array}$ & $\begin{array}{l}\text { Cement content } \\
\left(\mathrm{kg} / \mathrm{m}^{3}\right)\end{array}$ & $\begin{array}{l}\text { Gravel vol- } \\
\text { ume (\%) }\end{array}$ & $\begin{array}{l}\text { Wastes percent- } \\
\text { age (\%) }\end{array}$ & \\
\hline 1 & 0.49 & 375 & 0.4 & 5.25 & $9.54009 \mathrm{E}-07$ \\
\hline 2 & 0.55 & 412 & 0.55 & 7.5 & $1.02034 \mathrm{E}-06$ \\
\hline 3 & 0.55 & 340 & 0.55 & 7.5 & $1.14486 \mathrm{E}-06$ \\
\hline 4 & 0.45 & 412 & 0.45 & 3 & $1.00909 \mathrm{E}-06$ \\
\hline 5 & 0.55 & 412 & 0.55 & 3 & $1.00468 \mathrm{E}-06$ \\
\hline 6 & 0.49 & 375 & 0.49 & 5.25 & $1.07347 \mathrm{E}-06$ \\
\hline 7 & 0.49 & 375 & 0.49 & 9.75 & $1.0905 \mathrm{E}-06$ \\
\hline 8 & 0.45 & 340 & 0.45 & 7.5 & $1.14766 \mathrm{E}-06$ \\
\hline 9 & 0.55 & 340 & 0.45 & 7.5 & $1.01518 \mathrm{E}-06$ \\
\hline 10 & 0.55 & 340 & 0.45 & 3 & $9.99503 \mathrm{E}-07$ \\
\hline 11 & 0.55 & 412 & 0.45 & 3 & $8.9229 E-07$ \\
\hline 12 & 0.45 & 412 & 0.55 & 7.5 & $1.15344 \mathrm{E}-06$ \\
\hline 13 & 0.49 & 375 & 0.49 & 5.25 & $1.07347 \mathrm{E}-06$ \\
\hline 14 & 0.45 & 340 & 0.55 & 7.5 & 1.29237E-06 \\
\hline 15 & 0.49 & 375 & 0.49 & 0.75 & $1.05644 \mathrm{E}-06$ \\
\hline 16 & 0.45 & 340 & 0.55 & 3 & 1.27487E-06 \\
\hline 17 & 0.55 & 340 & 0.55 & 3 & 1.12959E-06 \\
\hline 18 & 0.49 & 375 & 0.49 & 5.25 & $1.07347 \mathrm{E}-06$ \\
\hline 19 & 0.49 & 445 & 0.49 & 5.25 & $9.71506 \mathrm{E}-07$ \\
\hline 20 & 0.45 & 340 & 0.45 & 3 & $1.12963 \mathrm{E}-06$ \\
\hline 21 & 0.6 & 375 & 0.49 & 5.25 & $9.46503 \mathrm{E}-07$ \\
\hline 22 & 0.45 & 412 & 0.45 & 7.5 & $1.02756 \mathrm{E}-06$ \\
\hline 23 & 0.49 & 375 & 0.6 & 5.25 & $1.21213 \mathrm{E}-06$ \\
\hline 24 & 0.49 & 375 & 0.49 & 5.25 & 1.07347E-06 \\
\hline 25 & 0.49 & 375 & 0.49 & 5.25 & 1.07347E-06 \\
\hline 26 & 0.55 & 412 & 0.45 & 7.5 & $9.08294 \mathrm{E}-07$ \\
\hline 27 & 0.49 & 305 & 0.49 & 5.25 & $1.21513 \mathrm{E}-06$ \\
\hline 28 & 0.4 & 375 & 0.49 & 5.25 & 1.21117E-06 \\
\hline 29 & 0.49 & 375 & 0.49 & 5.25 & 1.07347E-06 \\
\hline 30 & 0.45 & 412 & 0.55 & 3 & $1.13543 \mathrm{E}-06$ \\
\hline
\end{tabular}

\subsection{The simultaneous and reciprocal effects of variables}

In this part, the simultaneous and reciprocal (interaction) effect of independent variables on the ratio of tensile strength to construction cost is investigated.

\subsubsection{The simultaneous and reciprocal effects of water to cement ratio and cement content}

Figure 3 shows the amount of tensile strength to cost while the gravel volume and the percentage of wastes is respectively equal to $0.5 \%$ and $5.25 \%$. Also, the parameters of water to cement ratio and the cement content are variable in the range of $0.45-0.55$ and $340-410 \mathrm{~kg} / \mathrm{m}^{3}$. Figure $3 a$ states that increasing the cement content and the water to cement ratio, the response value is reduced. So that, the highest response value is achieved in the water to cement ratio of 0.55 and the cement content of $340 \mathrm{~kg} / \mathrm{m}^{3}$. In addition, crossover lines in Fig. $3 \mathrm{~b}$ show the reciprocal effects and interaction between the two parameters; it is obvious that increasing the cement content affects and reduces the water to cement ratio.

\subsubsection{The simultaneous and reciprocal effects of water to cement ratio and waste percentage}

The effect of water to cement ratio (in the range of $0.45-0.55$ ) and wastes (with values of 3-7.5\%) on the ratio of tensile strength to cost, by the cement content of $376 \mathrm{~kg} / \mathrm{m}^{3}$ and gravel volume of $0.5 \%$, is shown in Fig. 4 a. Accordingly, increasing both water to cement ratio and waste percentage has reduced the response value. Due to 


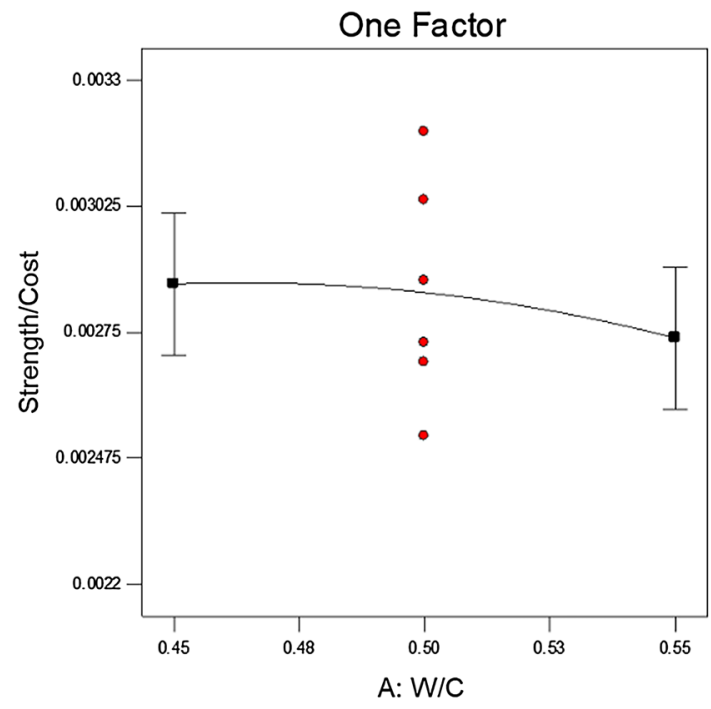

(a) The effect of the water to cement ratio on the response based on constant values of others (D: Waste percent= 5.25; $\mathrm{C}$ : Gravel volume $=0.5$; B: Cement Content $=376$ )

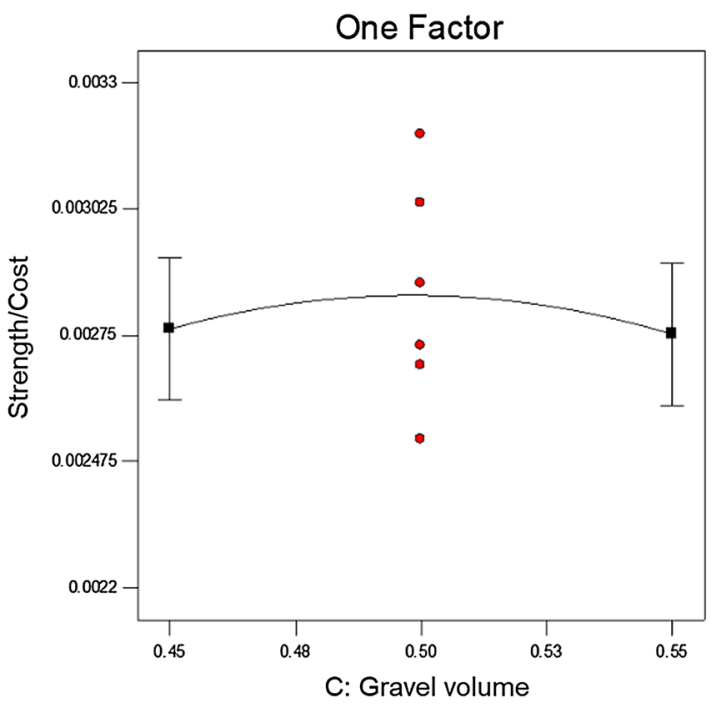

(c) The effect of gravel volume on the response based on constant values of others $(\mathrm{D}$ : Waste percent $=5.25$; $\mathrm{B}$ : Cement Content $=376 ; \mathrm{A}: \mathrm{W} / \mathrm{C}=0.5$ )

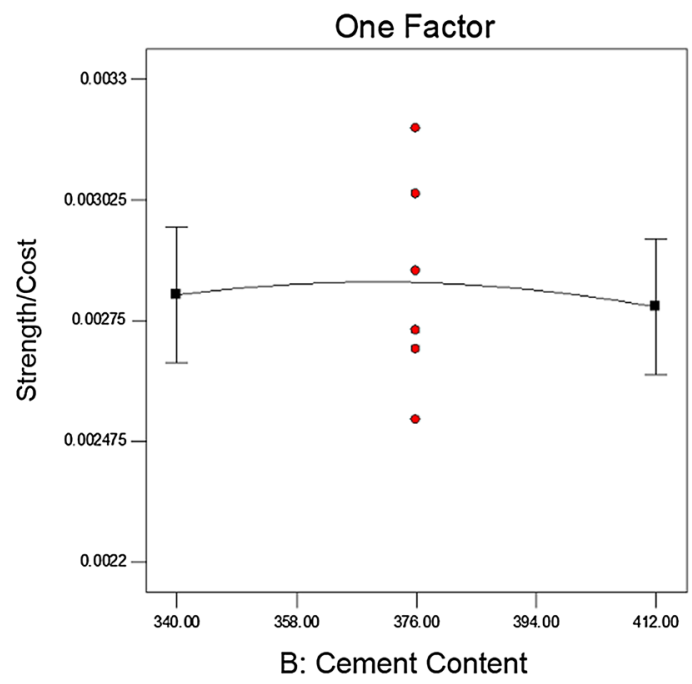

(b) The effect of cement content on the response based on constant values of others (D: Waste percent= 5.25; $\mathrm{C}$ : Gravel volume $=0.5 ; \mathrm{A}: \mathrm{W} / \mathrm{C}=0.5$ )

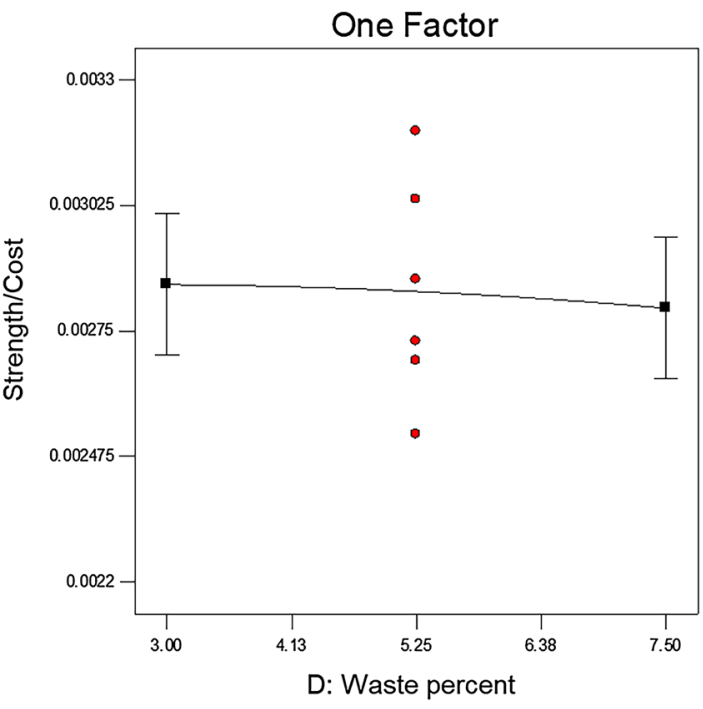

(d) The effect of waste percentage on the response based on constant values of others $(\mathrm{C}$ : Gravel volume $=0.5$; $\mathrm{B}$ : Cement Content=376; $\mathrm{A}: \mathrm{W} / \mathrm{C}=0.5$ )

Fig. 2 Effect of each independent variable on the response

the parallelism of the lines in Fig. $4 \mathrm{~b}$, it can be concluded that there is no interaction between them.

\subsubsection{The simultaneous and reciprocal effects of water to cement ratio and gravel volume}

Figure 5 a shows the effect of gravel volume $(0.45-0.55 \%)$ and water to cement ratio $(0.45-0.55)$ on tensile strength to cost ratio, while the cement content of $376 \mathrm{~kg} / \mathrm{m}^{3}$ and the wastes percentage of $25.5 \%$. This figure indicates that increase in the gravel volume increases the response value. When the water to cement ratio increases, the amount of response is reduced. So that, the highest amount of response is obtained in the gravel volume of $0.55 \%$ and the water to cement ratio of 0.45 . On the other hand, as shown in Fig. 5b, there is little interaction between the two parameters. 


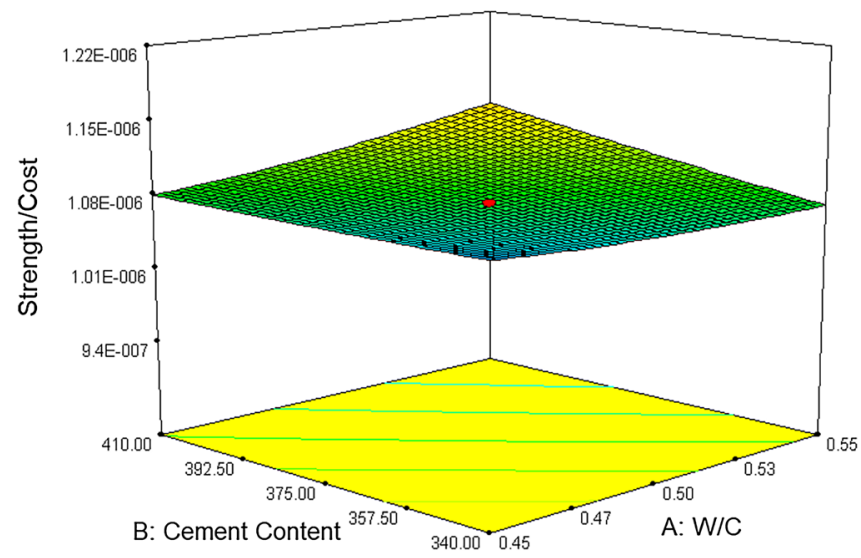

(a) The simultaneous effect of cement content and water to cement ratio on the response

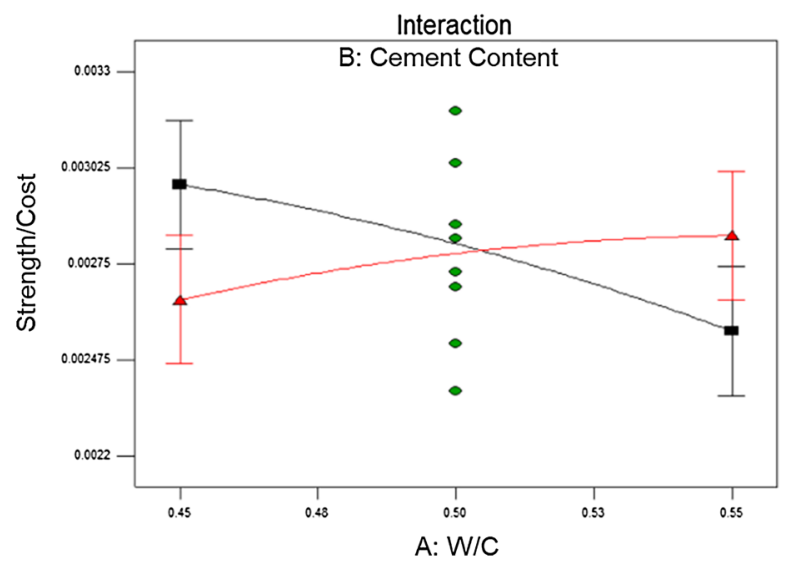

(b) The reciprocal effect of cement content and water to cement ratio on the response

Fig. 3 The simultaneous and reciprocal effects of cement content and water to cement ratio on the response (tensile strength to cost ratio) based on constant values of others ( $D$ : Waste percent $=5.25 ; C$ : Gravel volume $=0.5$ )

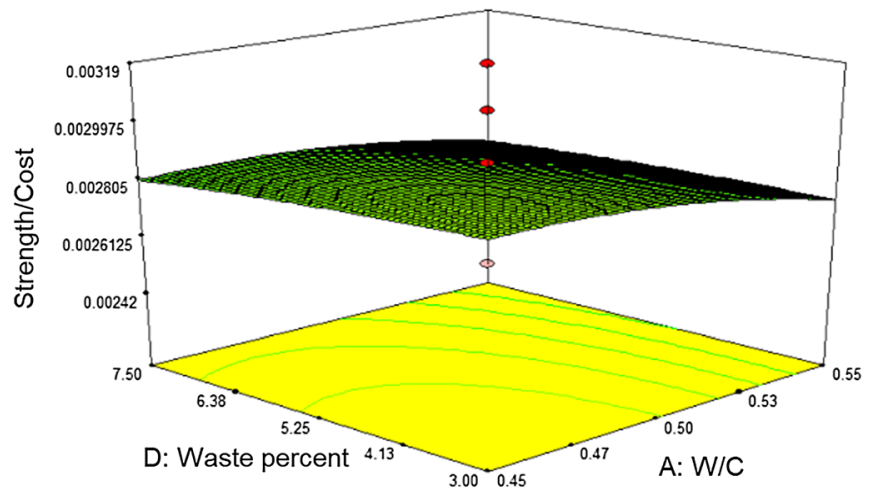

(a) The simultaneous effect of water to cement ratio and waste percentage on the response

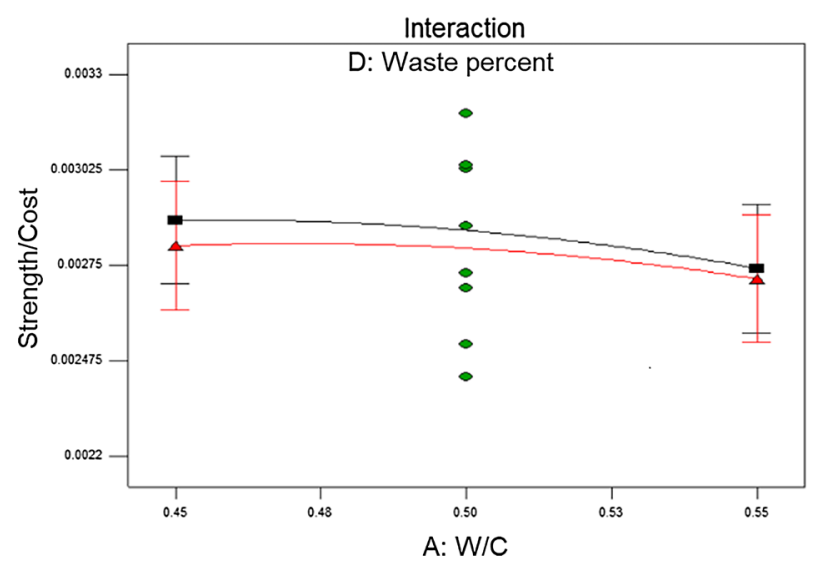

(b) The reciprocal effect of water to cement ratio and waste percentage on the response

Fig. 4 The simultaneous and reciprocal effects of water to cement ratio and waste percentage on the response (tensile strength to cost ratio) based on constant values of others ( $\mathrm{C}$ : Gravel volume $=0.5 ; \mathrm{B}$ : Cement Content $=376$ )

\subsubsection{The simultaneous and reciprocal effects of cement content and gravel volume}

The effect of gravel volume (in the range of $0.45-0.55 \%$ ) and cement content (with values of $340-410 \mathrm{~kg} / \mathrm{m}^{3}$ ) on the ratio of response, in the case of constant value of water to cement ratio and wastes percentage of 0.5 and $25.5 \%$ respectively, is displayed in Fig. 6 a. As can be observed, the effect of the gravel volume is greater than the cement content, and is consistent with the deduction of model. In the case of the maximum amount of gravel volume and the least amount of cement content, the ratio of tensile strength to cost is maximized.
In Fig. 6b, parallel lines indicate no interaction between the two parameters.

\subsubsection{The simultaneous and reciprocal effects of cement content and waste percentage}

In Fig. 7a, the simultaneous effect of cement content $\left(340-412 \mathrm{~kg} / \mathrm{m}^{3}\right)$ and waste percentage $(3-7.5 \%)$ on the response is shown, while the other parameters have constant values (water to cement ratio and gravel volume both equal to 0.5 ). In this way, the simultaneous increase in the cement content and the wastes percentage led to slight variations in the response. According to Fig. 7b, due 


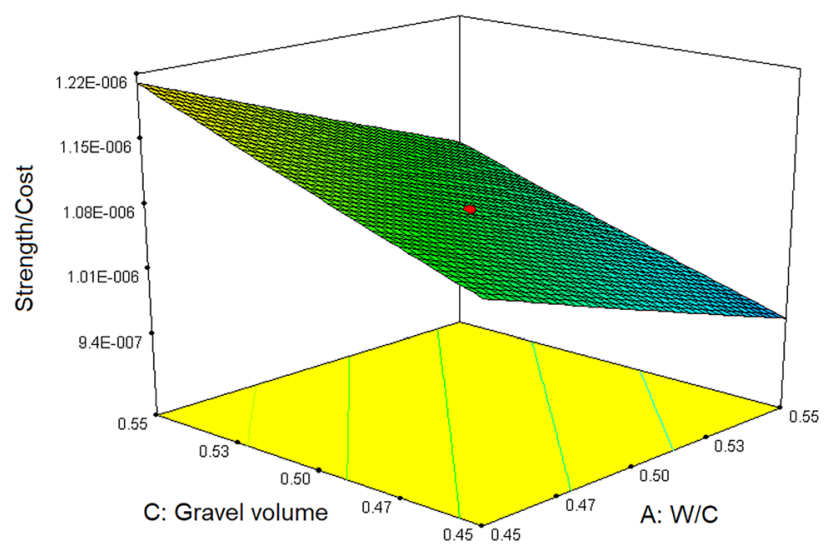

(a) The simultaneous effect of water to cement ratio and gravel volume on the response

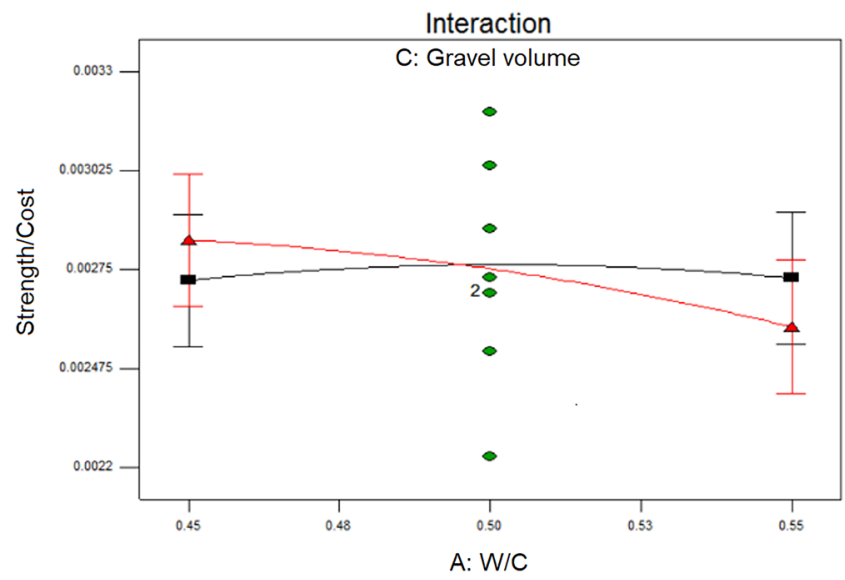

(b) The reciprocal effect of water to cement ratio and gravel volume on the response

Fig. 5 The simultaneous and reciprocal effects of water to cement ratio and gravel volume on the response (tensile strength to cost ratio) based on constant values of others ( $D$ : Waste percent $=5.25$; $B$ : Cement content $=376$ )

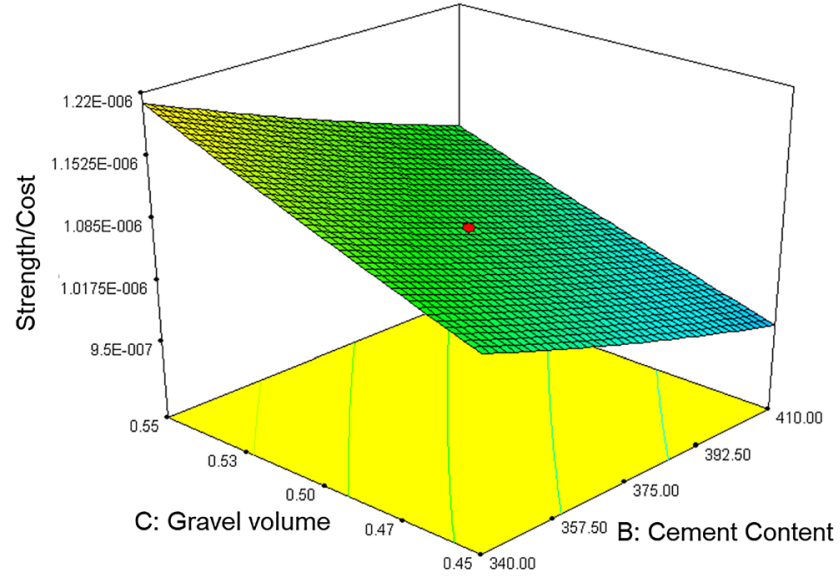

(a) The simultaneous effect of cement content and gravel volume on the response

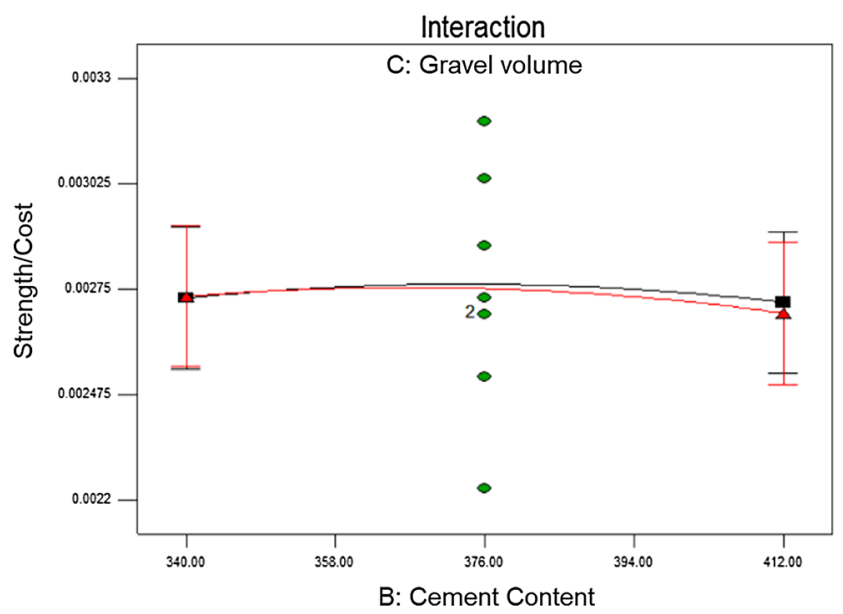

(b) The reciprocal effect of cement content and gravel volume on the response

Fig. 6 The simultaneous and reciprocal effects of cement content and gravel volume on the response (tensile strength to cost ratio) based on constant values of others ( $D$ : Waste percent $=5.25 ; A: W / C=0.5$ )

to the crossover of small-angle lines, a little interaction occurs between the two parameters.

\subsubsection{The simultaneous and reciprocal effects of gravel volume and waste percentage}

Figure 8a presents the amount of response while the water to cement ratio and the cement content are constant (respectively equal to 0.5 and $376 \mathrm{~kg} / \mathrm{m}^{3}$ ), and the gravel volume and wastes percentage are variable (respectively in the range of $0.45-0.55 \%$ and $3-7.5 \%$ ). It was concluded that simultaneously increasing the gravel volume and the wastes percentage, led to increase in the response. In addition, the interaction between the two parameters is given in Fig. 8b. As it has been observed so far, the two parameters of cement content and water to cement ratio have the highest interaction and the two parameters of cement and the wastes percentage have the least interaction. Also, the interaction between water to cement ratio and wastes percentage achieved zero. 


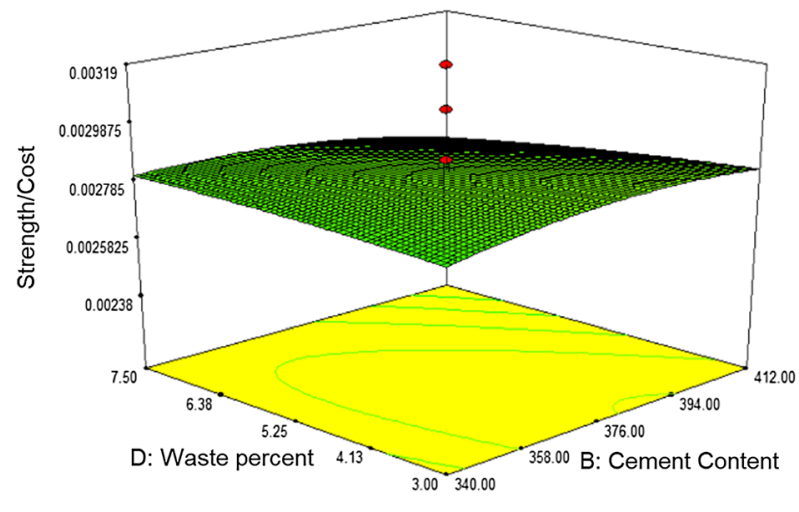

(a) The simultaneous effect of cement content and waste percentage on the response

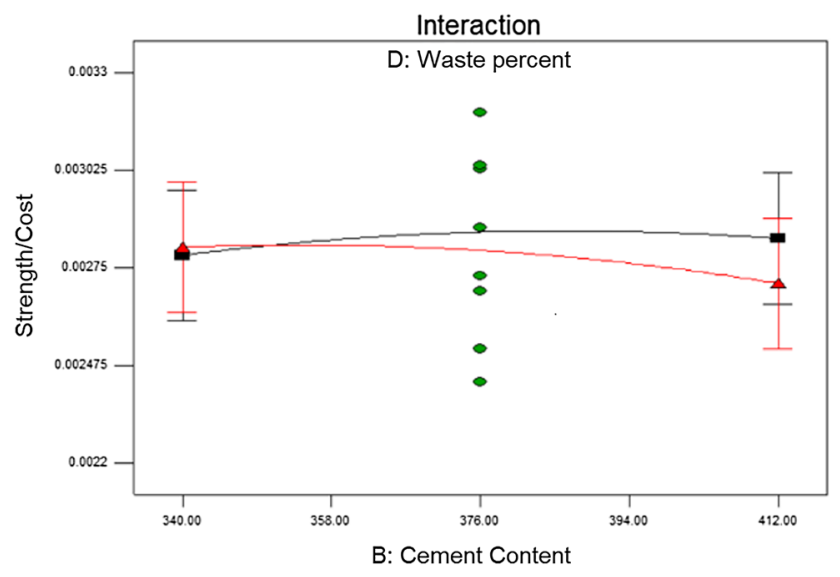

(b) The reciprocal effect of cement content and waste percentage on the response

Fig. 7 The simultaneous and reciprocal effects of cement content and waste percentage on the response (tensile strength to cost ratio) based on constant values of others ( $\mathrm{C}:$ Gravel volume $=0.5 ; \mathrm{A}: \mathrm{W} / \mathrm{C}=0.5$ )

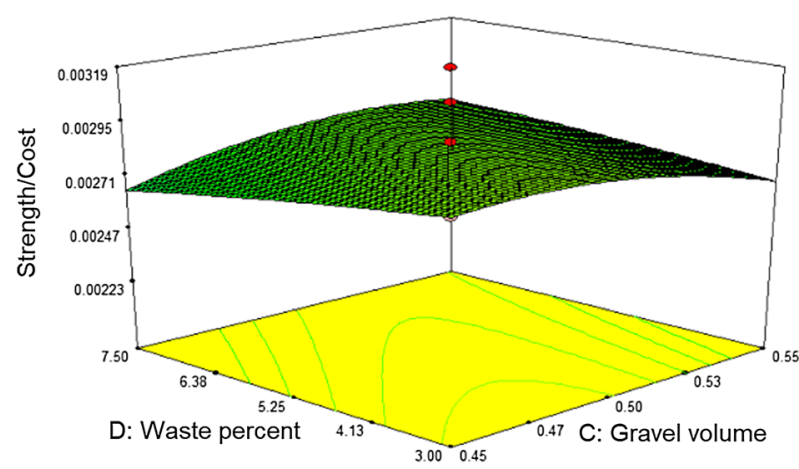

(a) The simultaneous effect of gravel volume and waste percentage on the response

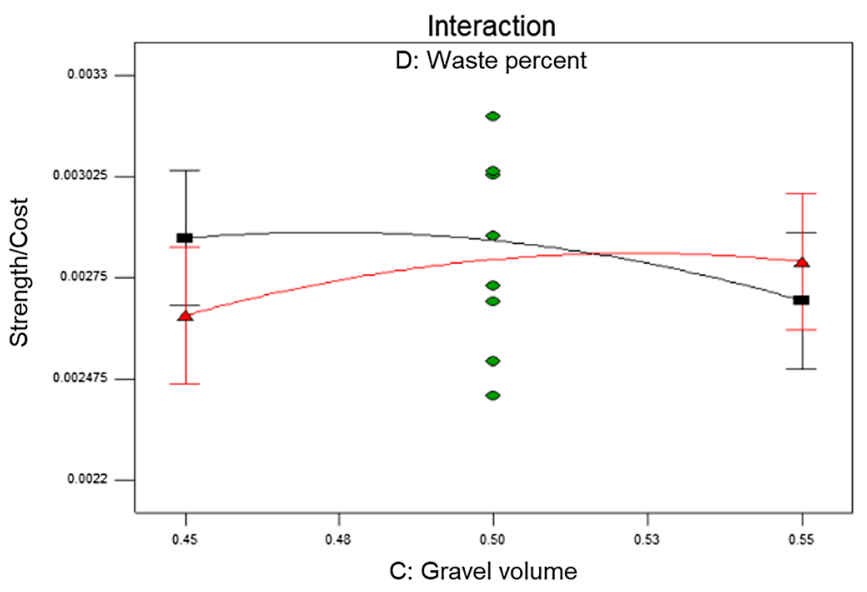

(b) The reciprocal effect of gravel volume and waste percentage on the response

Fig. 8 The simultaneous and reciprocal effects of gravel volume and waste percentage on the response (tensile strength to cost ratio) based on constant values of others ( $\mathrm{B}$ : Cement Content $=376 ; \mathrm{A}: \mathrm{W} / \mathrm{C}=0.5$ )

\subsection{Variance analysis of the results and presentation of the model}

After selecting the second-order quadratic model, analysis and optimization of the results, the ANOVA and correlation coefficient $\left(R^{2}\right)$ were obtained. According to the ANOVA presented in Table 6 , the model is significant with a $P$ value of $<0.0001$ and $R^{2}$ equal to 0.99 . In fact, the low $P$ value and high F-value for the response confirm the model accuracy with confidence level of $95 \%$. The obtained model is presented in Eq. (1) to predict the ratio of tensile strength to cost of the concrete.
The values of $A, B, C$ and $D$, respectively, indicate the amount of water to cement ratio, cement content, gravel volume and waste percentage. Their multiplication also indicates the interference of the parameters. It should be noted that the terms of $A D, B D, C D$, and $D^{2}$ with the $P$ value greater than 0.05 , were discarded at the model analysis. Therefore, the final modified model, in terms of coded values of the factors, is presented in Eq. (2). As elicited, from the 4 factors, the water to cement ratio, gravel volume, cement content, gravel volume and then waste percentage, had the highest effect on the tensile strength to cost ratio. 
Table 6 ANOVA for response surface quadratic model to identify the concrete mixing plan

\begin{tabular}{llrlrr}
\hline Source & Sum of squares & $d f$ & Mean square & F-value & $P$ value \\
\hline Model & $2.969 \mathrm{E}-13$ & 14 & $2.121 \mathrm{E}-14$ & 14792.96 & $<0.0001$ \\
A-W/C & $1.046 \mathrm{E}-13$ & 1 & $1.046 \mathrm{E}-13$ & 72973.47 & $<0.0001$ \\
B-Cement content & $9.001 \mathrm{E}-14$ & 1 & $9.001 \mathrm{E}-14$ & 62779.00 & $<0.0001$ \\
C-Gravel volume & $9.915 \mathrm{E}-14$ & 1 & $9.915 \mathrm{E}-14$ & 69155.75 & $<0.0001$ \\
D-Waste percent & $1.713 \mathrm{E}-15$ & 1 & $1.713 \mathrm{E}-15$ & 1194.52 & $<0.0001$ \\
AB & $1.923 \mathrm{E}-16$ & 1 & $1.923 \mathrm{E}-16$ & 134.13 & $<0.0001$ \\
AC & $2.100 \mathrm{E}-16$ & 1 & $2.100 \mathrm{E}-16$ & 146.13 & $<0.0001$ \\
AD & $5.515 \mathrm{E}-18$ & 1 & $5.515 \mathrm{E}-18$ & 3.85 & 0.0687 \\
BC & $3.336 \mathrm{E}-16$ & 1 & $3.336 \mathrm{E}-16$ & 232.66 & $<0.0001$ \\
BD & $1.732 \mathrm{E}-19$ & 1 & $1.732 \mathrm{E}-19$ & 0.12 & 0.7330 \\
CD & $1.890 \mathrm{E}-19$ & 1 & $1.890 \mathrm{E}-19$ & 0.13 & 0.7216 \\
A2 & $2.901 \mathrm{E}-17$ & 1 & $2.901 \mathrm{E}-17$ & 20.23 & 0.0004 \\
B2 & $5.928 \mathrm{E}-16$ & 1 & $5.928 \mathrm{E}-16$ & 413.45 & $<0.0001$ \\
C2 & $1.194 \mathrm{E}-16$ & 1 & $1.194 \mathrm{E}-16$ & 83.25 & $<0.0001$ \\
D2 & $2.699 \mathrm{E}-18$ & 1 & $2.699 \mathrm{E}-18$ & 1.88 & 0.1902 \\
Residual & $2.151 \mathrm{E}-17$ & 15 & $1.434 \mathrm{E}-18$ & & \\
Pure error & 0.000 & 5 & 0.000 & & \\
Cor total & $2.97 \mathrm{E}-13$ & 29 & & & \\
\hline
\end{tabular}

$$
\begin{aligned}
& \text { Strength/Cost }(\$)=+1.07 E-6-6.6 E-8 A-6.12 E \\
& \quad-8 B+6.42 E-8 C+8.45 E-9 D+3.46 E-9 A C-5.87 E \\
& -10 A D-4.56 E-9 B C+1.04 E-10 B D-1.08 E-10 C D \\
& +1.03 E-9 A^{2}+4.65 E-9 B^{2}+2.08 E-9 C^{2}-3.14 E-10 D^{2}
\end{aligned}
$$

Strength/Cost $(\$)=+1.07 \mathrm{E}-6-6.6 \mathrm{E}-8 \mathrm{~A}-6.12 \mathrm{E}-8 \mathrm{~B}+6.42 \mathrm{E}$

$$
\begin{aligned}
& -8 C+8.45 E-9 D+3.46 E-9 A B \\
& -3.62 E-9 A C-4.56 E-9 B C+1.07 E \\
& -9 A^{2}+4.69 E-9 B^{2}+2.13 E-9 C^{2}
\end{aligned}
$$

\subsection{Model validation}

Figure 9 shows the predicted values of the statistical model versus the actual values obtained from the tensile strength to cost of the concrete. The high conformity of the points on the 45-degree line expresses the model ability to predict the response.

\subsection{Determining the optimum conditions}

The purpose of the modeling is to find meaningful factors and predict the response by a few number of experiments. After modeling, it is necessary to predict the optimum conditions and evaluation the confidence level of the proposed model by a confirmation test. In this research, the best conditions for the concrete mixing plan with the desirability degree of 1 obtained equal to $A=0.45, B=340 \mathrm{~kg} / \mathrm{m}^{3}$, $C=0.55 \%$ and $D=7.5 \%$, respectively, for water to cement

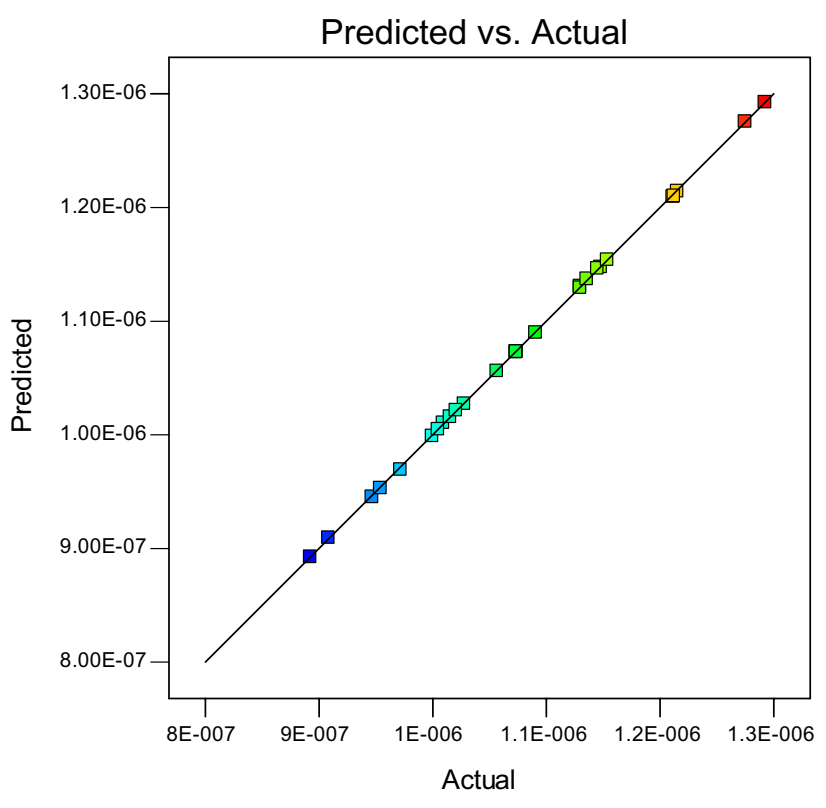

Fig. 9 Predicted values of the response by statistical model versus actual values obtained from the tested mixing plan of the concrete

ratio, cement content, gravel volume and waste percentage. In order to ensure the optimum conditions, a repeat test was carried out under above conditions. In Table 7, the results of the experiments by optimum conditions and suggested values of the model are presented. Accordingly, the achieved response is very close to the proposed value of model; plus, the confidence level is in the range of $95 \%$. The results of confirmation tests, after two repetitions, were 
Table 7 Predicted response of the model and obtained one from confirmation test

\begin{tabular}{llllll}
\hline Response & Goal & Predicted value & $95 \% \mathrm{Cl}$ high & $0.95 \% \mathrm{Cl}$ low & $\begin{array}{l}\text { Confirma- } \\
\text { tion test } \\
\text { values }\end{array}$ \\
\hline Tensile strength to cost ratio & Maximum & $1.2924 \mathrm{E}-6$ & $1.294 \mathrm{E}-6$ & $1.291 \mathrm{E}-6$ & $\begin{array}{l}1.2932 \mathrm{E}-6 \\
1.2914 \mathrm{E}-6\end{array}$ \\
\hline
\end{tabular}

reported. As can be observed, the results of both tests are in the acceptable range. In continue, the control test was performed with the same conditions as the optimum test (without coal waste), which showed a difference of less than $5 \%$ in the response.

\section{Conclusions}

In this study, in order to feasibility study the cement replacement with coal waste in concrete mix design, the tensile strength and cost of concrete with different values of water to cement ratio, cement content, gravel volume and wastes were evaluated. For this purpose, 30 tests were designed with Response Surface Methodology. By determining the optimum conditions for the concrete mixing plan, the results of the tensile strength to cost ratio were compared to the control concrete sample (without cement replacement with coal waste). After the preparation of concrete samples according to the mixing designs of Design Expert software and determining the ratio of tensile strength to cost, the optimum conditions for water to cement ratio, cement content, gravel volume and wastes were achieved $0.45,340 \mathrm{~kg} /$ $\mathrm{m}^{3}, 0.55 \%$ and $7.5 \%$ respectively. In this case, the response value (tensile strength to cost ratio) was $1.29 \mathrm{E}-6 \mathrm{MPa} / \mathrm{USD}$. These conditions resulted a difference of less than $5 \%$ in the ratio of tensile strength to cost, compared to the control test with the same mixing plan (without the coal waste). Through this research, it was observed that use of coal waste as concrete material, in addition to reducing the consumption of natural materials and protecting the environment, reduces the cost of construction.

\section{Compliance with ethical standards}

Conflict of interest The authors declare that they do not have conflict of interest.

\section{References}

1. Aggarwal $P$, Aggarwal $Y$, Gupta SM (2007) Effect of bottom ash as replacement of fine aggregates in concrete. Asian J Civ Eng (Build Hous) 8(1):49-62
2. Akihiko Y, Takashi Y (1996) Study of utilization of copper slag as fine aggregate for concrete. Ashikaya Kogyo Daigaku Kenkyu Shuroku 23:79-85

3. Asadi P, Amini Rad H, Qaderi F (2019) Comparison of Chlorella vulgaris and Chlorella sorokiniana pa.91 in post treatment of dairy wastewater treatment plant effluents. Environ Sci Pollut Res. https://doi.org/10.1007/s11356-019-06051-8

4. Babanezhad E, Amini Rad H, HosseiniKarimi SS, Qaderi F (2017) Investigating nitrogen removal using simultaneous nitrification-denitrification in transferring wastewater through collection networks with small-diameter pipes. Water Pract Technol 12:396-405. https://doi.org/10.2166/wpt.2017.044

5. Babanezhad E, Qaderi F, Salehi Ziri M (2018) Spatial modeling of groundwater quality based on using Schoeller diagram in GIS base: a case study of Khorramabad, Iran. Environ Earth Sci 77:339. https://doi.org/10.1007/s12665-018-7541-0

6. Bhikshma V, Manipal K (2012) Study on mechanical properties of recycled aggregate concrete containing steel fibers. Asian J Civ Eng (Build Hous) 13(2):155-164

7. Brindha D, Nagan S (2011) Durability studies on copper slag admixed concrete. Asian J Civ Eng (Build Hous) 12(5):563-578

8. Ebrahimi Ghadi M, Qaderi F, Babanezhad E (2018) Prediction of mortality resulted from $\mathrm{NO}_{2}$ concentration in Tehran by Air Q + software and artificial neural network. Int J Environ Sci Technol 16(3):1351-1368. https://doi.org/10.1007/s1376 2-018-1818-4

9. Energy Statistics (2013) National Statistical Organization, Ministry of statistics and programme implementation, Government of India

10. Heidari GM, Sarrafi A, Kakueinejad A (2010) Feasibility study of consuming the Zarand coal mine waste in the process of cement production as alternative fuel and raw materials. In: National Conference on Energy and Environment of Kerman, Shahid Bahonar university of Kerman

11. Faghih Nasiri E, Yousefi Kebria D, Qaderi F (2019) The degradation of phenol in water solution by immobilized $\mathrm{TiO}_{2}$ photocatalysis. J Civ Environ Eng 48(93):43-49

12. Faghih Nasiri E, Yousefi Kebria D, Qaderi F (2018) An experimental study on the simultaneous phenol and chromium removal from water using titanium dioxide photocatalyst. Civ Eng J 4(3):585-593. https://doi.org/10.28991/cej-0309117

13. Huggins FE (2002) Overview of analytical methods for inorganic constituents in coal. Int J Coal Geol 50:169-214. https ://doi.org/10.1016/S0166-5162(02)00118-0

14. Khalegh R, Qaderi F (2019) Optimization of the effect of nanoparticle morphologies on the cost of dye wastewater treatment via ultrasonic/photocatalytic hybrid process. Appl Nanosci. https://doi.org/10.1007/s13204-019-00984-9

15. Khankhaje E, Hussin MW, Mirza J, Rafieizonooz M, Salim MR, Siong HC, Warid MNM (2016) On blended cement and geopolymer concretes containing palm oil fuel ash. Mater Des 89:385-398. https://doi.org/10.1016/j.matdes.2015.09.140 
16. Kim HK, Lee HK (2011) Use of power plant bottom ash as fine and coarse aggregates in high-strength concrete. Constr Build Mater 25(2):1115-1122. https://doi.org/10.1016/j.conbuildma t.2010.06.065

17. Kumar RR, Jagadeesh P, Rao PRM (2016) Strength properties of concrete containing coal washery rejects as coarse aggregate. Asian J Civ Eng (BHRC) 17:859-867

18. Manz OE (1997) Worldwide production of coal ash and utilization in concrete and other products. Fuel 76(8):691-696. https ://doi.org/10.1016/S0016-2361(96)00215-3

19. Mary OL, Krishnan VR (2016) Experimental investigations on the use of coal mine overburden as partial replacement for fine aggregate. Innov Res Sci Eng Technol 5(12):20414-20418. https ://doi.org/10.15680/IJIRSET.2016.0512023

20. Martins IMM, Gonçalves A, Marques JC (2010) Durability and strength properties of concrete containing coal bottom ash. In: Proceedings pro077: international RILEM conference on material science-AdIPoC-additions improving properties of concretetheme 3. RILEM Publications SARL, pp 275-283

21. Memon FA, Memon NA, Memon RA, Ursani AA, Umrani AW, Umrani FA, Laghari KQ, Lashari BK, Memon HM, Umrani FA, Ursani AA (2010) Study of compressive strength of concrete with coal power plant fly ash as partial replacement of cement and fine aggregate. Mehran Univ Res J Eng Technol 29(4):647-652

22. Modarres A, Rahmanzadeh M (2014) Application of coal waste powder as filler in hot mix asphalt. Constr Build Mater 66:476483. https://doi.org/10.1016/j.conbuildmat.2014.06.002

23. Naqipour M, Tazikeh M, Hoseinian B (2016) The use of coal waste in concrete construction and survey of compressive strength. J Concr Rese 9(2):43-53

24. Neville AM, Brooks JJ (2010) Concrete technology, 2nd edn. Prentice Hall, Upper Saddle River

25. Pajoum Shariati F, Qaderi F, Haeri H (2019) Using moving bed biofilm reactor including kaldness media in treatment of wastewater containing light component petroleum. J Civ Environ Eng 49:1-19

26. Qaderi F, Ayati B, Ganjidoust H (2011) Role of moving bed biofilm reactor and sequencing batch reactor in biological degradation of formaldehyde wastewater. J Environ Health Sci Eng 8:295-306

27. Qaderi F, Ayati B, Ganjidoust H (2012) Comparing the efficiency of MBBR and SBR in treating wastewater containing formaldehyde. Amirkabir J Civ Eng 43(2):43-50

28. Qaderi F, Ayati B (2014) Comparison of MBBR and SBAR in treating toxic formaldehyde wastewater. J Civ Environ Eng 44(74):99-106

29. Qaderi F, Ayati B, Ganjidoost H, Sarraf Mamoori R (2015) Treatment of wastewater containing acid orange 7 using ozonation process and determination of the intermediate by-products. J Water Wastewater 26(2):13-23

30. Qaderi F, Ayati B, Ganjidoust H, Sarraf-Mamoory R (2015) Investigation of kinetic and intermediate products of acid orange 7 removal by hybrid ozonation/photocatalytic processes. Modares J Civ Eng 15(2):79-89

31. Qaderi F, Babanezhad E (2017) Prediction of the groundwater remediation costs for drinking use based on quality of water resource, using artificial neural network. J Clean Prod 161:840849. https://doi.org/10.1016/j.jclepro.2017.05.187

32. Qaderi F, Asadi P, Tamadoni A, Azizi M (2018) Evaluation of sustainability of development in zone 22 of Tehran by ecological footprint method. Geogr Dev Iran J 16(50):231-245. https://doi. org/10.22111/gdij.2018.3575

33. Qaderi F, Sayahzadeh AH, Azizi M (2018) Efficiency optimization of petroleum wastewater treatment by using of serial moving bed biofilm reactors. J Clean Prod 192:665-677. https://doi. org/10.1016/j.jclepro.2018.04.257
34. Qaderi F, Sayahzadeh AH, Azizpour F, Vosughi P (2018) Efficiency modeling of serial stabilization ponds in treatment of phenolic wastewater by response surface methodology. Int J Environ Sci Technol 16(8):4193-4202. https://doi.org/10.1007/s1376 2-018-1816-6

35. Qaderi F, Sayahzadeh AH, Ebrahimi Ghadi M (2019) Optimization of effective environmental parameters on Astrazon Red GTL removal by dominant species Bacillus and Aeromonas: in a concurrent culture study. J Mol Cell Res 32(1):1-15

36. Rafieizonooz M, Mirza J, Salim MR, Hussin MW, Khankhaje E (2016) Investigation of coal bottom ash and fly ash in concrete as replacement for sand and cement. Constr Build Mater 116:15-24. https://doi.org/10.1016/j.conbuildmat.2016.04.080

37. Rafieizonooz M, Salimb MR, Hussinc MW, Mirzac J, Yunusb SM, Khankhajea E (2017) Workability, compressive strength and leachability of coal ash concrete. Chem Eng 56:439-444. https ://doi.org/10.3303/CET1756074

38. Raju R, Paul MM, Aboobacker KA (2014) Strength performance of concrete using bottom ash as fine aggregate. Res Eng Technol 2(9):111-122

39. Saikia N, Brito JD (2012) Use of plastic waste as aggregate in cement mortar and concrete preparation: a review. Constr Build Mater 34:385-401. https://doi.org/10.1016/j.conbuildma t.2012.02.066

40. Santos CRD, Amaral Filho JRD, Pagnussat D, Schneider IAH, Tubino RMC (2012) Use of coal waste as fine aggregates in concrete blocks for paving. In: 10th International conference on concrete block paving shanghai, Peoples Republic of China, 24-26 Nov

41. Santos CRD, Amaral Filho JRD, Tubino RMC, Schneider IAH (2013) Use of coal waste as fine aggregates in concrete paving blocks. Geomaterials 3(2):54-59. https://doi.org/10.4236/ gm.2013.32007

42. Santos CRD, Tubino RMC, Schneider IAH (2015) Mineral processing and characterization of coal waste to be used as fine aggregates for concrete paving blocks. Revista IBRACON de Estruturas e Materiais 8(1):14-24. https://doi.org/10.1590/S1983-41952 015000100004

43. Sheikholeslami Z, YousefiKebria D, Qaderi F (2018) Nanoparticle for degradation of BTEX in produced water; an experimental procedure. J Mol Liq 246:476-482. https://doi.org/10.1016/j. molliq.2018.05.096

44. Sheikholeslami Z, Yousefi Kebria D, Qaderi F (2019) Investigation of photocatalytic degradation of BTEX in produced water using $\mathrm{Fe}_{2} \mathrm{O}_{3}$ nanoparticle. J Therm Anal Calorim 135(3):1617-1627. https://doi.org/10.1007/s10973-018-7381-x

45. Shi DS, Han P, Ma Z, Wang JB (2012) Report of experimented on compressive strength of concrete using granulated blast furnace slag as fine aggregate. Adv Mater Res 575:100-103. https ://doi.org/10.4028/www.scientific.net/AMR.575.100

46. Siddique R, Khatib J, Kaur I (2008) Use of recycled plastic in concrete: a review. Waste Manag 28(10):1835-1852. https:// doi.org/10.1016/j.wasman.2007.09.011

47. Singh M, Siddique R (2015) Properties of concrete containing high volumes of coal bottom ash as fine aggregate. Clean Product 91:269-278. https://doi.org/10.1016/j.jclepro.2014.12.026

48. Soofinajafi M, Shafigh P, Akashah FW, Mahmud HB (2016) Mechanical properties of high strength concrete containing coal bottom ash and oil-palm boiler clinker as fine aggregates. In: MATEC web of conferences 66: 00034, EDP Sciences

49. Sudharshan J, Kumar RR (2017) Performance of coal washery reject and fly ash blended concrete in acidic environment. Int J Sci Res Dev (IJSRD) 5(2):394-397

50. Sumalatha A, Sree HS, Kumar RR (2016) Durability properties of fly ash blended concrete made with coal washery rejects as coarse aggregate. Int J Sci Res Dev (IJSRD) 4(10):383-386 
51. Taghizadeh M, Yousefi Kebria D, Qaderi F (2019) Benzene and toluene removal from saline water with coupled membrane process and nanophotocatalyst. J Pet Res 27(10300695):168-179

52. Tavakoli AD, Heidari A, Karimian M (2013) Properties of concretes produced with waste ceramic tile aggregate. Asian J Civ Eng 14(3):369-382

53. Tamadoni A, Qaderi F (2019) Optimization of soil remediation by ozonation for PAHs contaminated soils. Ozone Sci Eng 41(5):454-472. https://doi.org/10.1080/01919512.2019.16158 65

54. Tavakoli Moghadam M, Qaderi F (2019) Modeling of petroleum wastewater treatment by $\mathrm{Fe} / \mathrm{Zn}$ nanoparticles using the response surface methodology and enhancing the efficiency by scavenger. Results Phys 15:102566-102576. https://doi. org/10.1016/j.rinp.2019.102566

55. Tumingan MWT, Djamaluddin R, Sampebulu V (2014) Compression strength of concrete with pond ash as replacement of fine aggregate. ARPN J Eng Appl Sci 9(12):2923-2928
56. Valcuende M, Benito F, Parra C, Miñano I (2015) Shrinkage of self-compacting concrete made with blast furnace slag as fine aggregate. Constr Build Mater 76:1-9. https://doi.org/10.1016/j. conbuildmat.2014.11.029

57. Yavari SM, Qaderi F (2018) Determination of thermal pollution of water resources caused by Neka power plant through processing satellite imagery. Environ Dev Sustain. https://doi. org/10.1007/s10668-018-0272-2

58. Zeghichi $L$ (2006) The effect of replacement of naturals aggregates by slag products on the strength of concrete. Asian J Civ Eng (Build Hous) 7(1):27-35

Publisher's Note Springer Nature remains neutral with regard to jurisdictional claims in published maps and institutional affiliations. 